Seyahat ve Otel İşletmeciliği Dergisi/

Journal of Travel and Hospitality Management

17(1), 2020, 71-86

Gönderim Tarihi: 20.11 .2019

Kabul Tarihi: 28.01.2020

DOI: $10.24010 /$ soid.639924

\title{
Kişiliğin Karanlık Üçlüsü: Turizm Sektöründe Demografik Değişkenler Açısından Bir İnceleme
}

\section{The Dark Triad of Personality: A Research on Demographic Variables in Tourism Sector}

\author{
Dr. Esin YÜCEL \\ Akdeniz Üniversitesi \\ Akdeniz Uygarlıkları Araştırma Enstitüsü \\ E-posta: esinyucel@akdeniz.edu.tr
}

Öz

Bu çalışmanın amacı turizm sektörü çalışanlarının karanlık kişilik özelliklerini belirlemek, bireysel ve demografik özelliklerin karanlık üçlü düzeyleri (subklinik narsisizm, Makyavelizm ve subklinik psikopati) üzerinde farklılığa sebep olup olmadığını ortaya koymaktır. Araştırmanın evrenini Alanya'da faaliyet gösteren dört ve beş yıldızlı otel işletmelerinin çalışanları oluşturmaktadır. Araştırmada, çalışanların bireysel özelliklerini belirlemeye yönelik sorular ile karanlık üçlü ölçeği olmak üzere iki bölümden oluşan anket formu kullanılmıştır. 684 anket üzerinden yapılan değerlendirmeler için yüzde ve frekans analizi, t-testi, Anova testlerinden faydalanılmıştır. Yapılan analizler sonucunda otel çalışanlarının subklinik narsisizm düzeyleri, Makyavelizm ve subklinik psikopatiden daha fazladır. Cinsiyetin karanlık üçlünün tüm alt boyutlarında etkili olduğu sonucuna ulaşılmıştır. Ayrıca Makyavelizm ve subklinik narsisizmde medeni durum anlamlı farklılığa sebep olurken, yaş değişkeni sadece subklinik narsisizmde etkili olmuştur.

Anahtar Kelimeler: Karanlık Üçlü, Makyavelizm, Subklinik Narsisizm, Subklinik Psikopati.

\begin{abstract}
The aim of this study is to determine the dark personality traits of tourism sector employees and to determine whether individual and demographic characteristics cause differences on the dark triad levels. The population of the research consists of the employees of four and five star hotels operating in Alanya. In the research, two-part questionnaire form including questions to determine the individual characteristics of employees and dark triad scale were used. Percentage and frequency analysis, t test, Anova tests were used for evaluations made on 684 questionnaires. As a result of the analyzes, subclinical narcissism levels of hotel staff were higher than Machiavellianism and subclinical psychopathy. It was concluded that gender was effective in all subdimensions of the dark triad. In addition, while marital status caused a significant difference in Machiavellianism and subclinical narcissism, age variable was only effective in subclinical narcissism.
\end{abstract}

Key Words: Dark Triad, Machiavellianism, Subclinical Narcissism, Subclinical Psychopathy. 


\section{Giriş}

Kişilik özellikleri örgütsel bağlamda çoğunlukla olağan kişilik özellikleri çerçevesinde araştırmalara konu olmaktadır. Fakat bu durum ölçüm kriterleri arasında yer almayan menfaat odaklı olma, uyumsuzluk, ikiyüzlülük, manipülasyona başvurma, duygusal soğukluk gibi eğilimlerin örgütsel bağlamda değerlendirilmesine olanak tanımamaktadır. Kişilik özellikleri, bireylerin örgüt ortamında ve sosyal yaşantılarında sergiledikleri davranışların, dolayısıyla çalışma arkadaşlarına ve müşterilere karşı sergiledikleri tutum ve davranışların önemli bir belirleyicisidir (Sığrı ve Gürbüz, 2011: 31). Toplum içinde istenen/beklenen/olumlu kişilik özelliklerini taşıyan bireylerin yanında, karanlık yön olarak nitelendirilen bazı özelliklere sahip bireyler de mevcuttur.

Her ne kadar işletmeler personel alımlarında çeşitli eleme ölçütlerine dayanarak seçim yapsalar da tüm kişilik özelliklerinin bu aşamada tespit edilemeyeceği açıktır. Bu durumda, istihdam edilen karanlık kişilik özelliklerine sahip kişilerin nasıl yönetileceği sorunu karşımıza çıkmaktadır. Özellikle emek yoğun sektör olan turizm sektöründe, çalışanların kişilik özelliklerinin olumlu ve karanlık yönleri hem örgüt iklimini hem de hizmeti müşteriye doğrudan sundukları için hizmetin kalitesini, bunun sürdürülebilirliğini, müşteri memnuniyetini, sadakatini ve daha pek çok örgütsel çıktıyı etkileyecektir.

Uluslararası alan yazın incelendiğinde karanlık kişilik özellikleri olarak ifade edilen narsisizm, Makyavelizm ve psikopatinin sıklıkla araştırmalara konu olduğu görülmektedir. Son yıllarda iş yaşamında etik olmayan uygulamaların artması, yönetim alanındaki araştırmacıları kişilik özelliklerini olumlu boyutlarıyla değerlendirmenin yanında örgüt ve toplum açısından oluşturacağı potansiyel zararları göz önüne alarak karanlık yönünü de değerlendirmeye yöneltmiş ve araştırmalar karanlık kişilik özelliklerinin örgütsel çıktıları nasıl etkilediği üzerine odaklanmıştır (Brunell ve diğ., 2008; Penney ve Spector, 2002; Robinson ve O'Leary-Kelly, 1998; Amernic ve Craig, 2010; Galperin ve diğ., 2011; Rosenthal ve Pittinsky, 2006; Kiazad ve diğ., 2010; Kessler ve diğ., 2010; Harms ve diğ., 2014; Jones ve Paulhus, 2011; McDonald ve diğ., 2012; O'Boyle ve diğ., 2012; Furnham ve diğ., 2013; Maples ve diğ., 2014; Schyns, 2015; Jonason ve Webster, 2010; Skeem ve diğ., 2011; Jonason ve diğ., 2015; Spain ve diğ., 2013). Ulusal alan yazında ise bu konudaki çalışmaların azlığı (Kanten ve diğ., 2015; Özsoy ve Ardıç, 2017; Özsoy ve diğ., 2017(a;b); Özer ve diğ., 2016; Aydoğan ve Serbest, 2016; Özen Kutanis ve diğ., 2015) dikkat çekicidir. Ulusal alan yazında bu kişilik eğilimlerinin örgütsel bağlamda çeşitli değişkenler kapsamında incelenmesi bu özelliklerin olası örgütsel yansımalarının anlaşılmasına katkı sağlayacaktır.

Diğer taraftan, çalışanların sosyo-demografik özelliklerinin karanlık kişilik özelliğini açıklamadaki etkisini inceleyen az sayıda çalışma (Ergun Özler ve diğ., 2013; Özcihan, 2014; Hamedoğlu, 2009; Akıncı, 2015; Özer ve diğ., 2016; Aydoğan ve Serbest, 2016) olduğu ve bu konunun turizm sektörü kapsamında ele alınmadığı görülmektedir. Bu doğrultuda, bu çalışmada Alanya'da faaliyet gösteren 4 ve 5 yıldızlı otel çalışanlarının karanlık kişilik seviyelerini belirlemek ve bu özelliklerin demografik özelliklere göre farklılık gösterip göstermediğini ortaya koymak amaçlanmıştır. Veriler, otel işletmeleri çalışanlarından anket yoluyla toplanmıştır. Sonrasında bağımsız örneklem t-testi ve Anova testi uygulanarak sonuçlar teorik ve uygulama perspektifinden değerlendirilmiştir. Çalışmada öncelikle teorik çerçeve çizilmiş, araştırmanın yöntemi açıklanmış, son olarak da bulgular ilgili alan yazını ışığında tartışılmıştır. Sonuçların konuya ilgi duyan araştırmacılara ve sektör yöneticilerine katkı sağlayacağı düşünülmektedir. 


\section{Kavramsal Çerçeve}

\subsection{Karanlık Üçlü: Narsisizm, Makyavelizm ve Psikopati}

Paulhus ve Williams (2002) tarafından "The Dark Triad of Personality" olarak tanımlanan kavram, kişiliğin karanlık özellikleri olarak nitelendirilen narsisizm, Makyavelizm ve psikopati alt bileşenlerini kapsamaktadır. Her ne kadar alan yazında bu kavramın Paulhus ve Williams (2002) ile hayat bulduğu belirtilse de Harms ve Spain (2015) karanlık kişilik çalışmasının yeni olmadığını vurgulamışlardır. Yazarlara göre Emil Kraepelin'in 1907'de kaleme aldığı, rahatsız edici kişiliklerin yapısını anlatan ders kitabı karanlık kişilik kavramının doğduğu yer olarak nitelendirilmiştir. Harms ve Spain (2015), Kraepelin'in ahlaki delilik (sempati eksikliği, zulme eğilim ve öngörü eksikliği ile karakterize edilen), dengesizlik (huysuzluk, huzursuzluk ve ilgisizlik) yalancılık ve dolandırıcılık (başkalarını aldatmaktan zevk alma ve başkalarını başarısızlıkla suçlamaya eğilim) olarak nitelendirdiği kişilik özelliklerinin bugün psikopati, sınırda kişilik, paranoya ve Makyavelizm olarak etiketlendiğini belirtmektedirler.

\subsubsection{Subklinik Narsisizm}

Paulhus ve Williams (2002) narsisizm özelliğini subklinik narsisizm olarak tanımlamışlardır. Narsisizm, psikiyatri ve klinik psikoloji alanında bir kişilik bozukluğunu tanımlarken; subklinik narsisizm sosyal ve örgütsel psikoloji alanında kişilik özelliği olarak ele alınmaktadır. Pek çok noktada benzeşen tanımların farkı; subklinik narsisizmde narsisizm eğiliminin daha düşük olmasıdır. Ayrıca narsisizm klinik bir tanı iken subklinik narsisizmin tespiti kişinin kendi kendini değerlendirmesi yoluyla yapılmaktadır. Klinik bir hastalığın önceki safhasını ifade eden subklinik narsisizmde fark edilebilir klinik belirtiler bulunmamaktadır (Paulhus ve Williams, 2002; Campbell ve diğ., 2010).

Narsist birey kendisinde bulunan nitelikleri abartan, sahip olmadığı niteliklerle ayrı bir benlik inşa eden yapıya sahiptir. Kendisini eşsiz ve ayrıcalıklı hisseden birey başkalarının üzerinde otorite kurma eğilimindedir. Diğer insanların kendisini takip etmesini isteyen bireyde liderlik özelliğinin baskın olduğu söylenebilir. Diğer insanlardan üstün olduğunu düşünen narsist bireye göre kendisini sadece önemli insanlar anlayabilir çünkü diğerleri onu anlayacak donanıma sahip değildir. Narsistler için güç sahibi olmak çok önemlidir çünkü temelde psikolojik intiyaçların bastırılmış olduğu gerçeği vardır. Kendisine hayranlık duyulmasını isteyen birey dikkat çekme çabasındadır ve bunun için sahip olduklarıyla övünerek diğerlerinin gözünde daha güçlü, önemli ve çekici görünmeye çalışır. Çevresindeki insanlara değer vermeyen birey duygusal yakınlıktan hoşlanmaz, empati yapamaz, diğerlerine karşı kuşkucu ve güvensizdir. Kişisel ihtiyaçları ve menfaatleri her zaman ön planda bulunan birey, amaçlarına ulaşmak ve üstün/güçlü görünmek uğruna yalana başvurmaktan çekinmez. Eleştirilere kapalıdır ve eleştirilmek agresif tepkiler vermesine neden olabilir (Raskin ve Terry, 1988; Ames ve diğ., 2006; Campbell ve diğ., 2010; Jonason ve Webster, 2010; Campbell ve Miller, 2011; Jones ve Paulhus, 2014).

\subsubsection{Makyavelizm}

Makyavelizm kavramı, İtalyan düşünür ve politikacı Niccolò Machiavelli'nin düşünceleri üzerine kurulu bir yaklaşımdır. Devlet yönetimi ile ilgili düşüncelerinin temelini Prens adlı kitabında açıklayan Machiavelli için zafere giden her yol mubahtır. Niccolò Machiavelli'ye göre tüm insanlar bencil, ürkek, doymak bilmez, nankör ve içten pazarlıklıdır. Bu nedenle 
başarılı olmak ve kazanmak isteyen akıllı bir yönetici, gerektiğinde kötü olmak zorundadır.

Aslında Niccolò Machiavelli kendi adıyla anılan bakış açısını siyaset için tanımlamıştır. Ona göre siyasetçi, çıkarlarına aykırı olduğunda verdiği sözleri tutmayabilir. Başarıya ulaşması için halkı aldatması gerekiyorsa bunu hiç düşünmeden yapmalıdır. Aksi halde başarı mümkün değildir. 1970'lerde ise Christe ve Geis (1970), Niccolò Machiavelli'nin stratejisinin insanların kişilik özelliklerinde de bulunduğunu ve bireysel farklııkları tanımladığını iddia ederek "Makyavelizm"i bir kişilik özelliği olarak tanımlamışlardır. Makyavelist bireyler, hedeflerine ulaşmak için yalan söylemek, hile yapmak gibi yollara başvurmayı meşru görürler. Hedefe ulaşmak için önemli insanlara yakın olmak isterler çünkü onlar hedefe ulaşma yolunda güç sahibi kişilerdir. Şahsi çıkarları uğruna olayları ve kişileri çok rahat şekilde manipüle edebilen Makyavelist bireyler için diğerleri güvenilmezdir ve onlarla bilgi paylaşılmamalıdır. Dışadönük olmakla beraber, samimi değillerdir ve diğerleriyle ilişkilerinde ikiyüzlüdürler. Diğerlerini yönetebilmek için gerçekleri değil onların duymak istediklerini söylemeyi tercih ederler. Toplumsal ve ahlaki değerleri küçümsedikleri için çevrelerindeki bireyleri kendi menfaatleri uğruna kullanmaktan ve ahlaka aykırı davranışlardan çekinmezler (Nagler ve diğ., 2014; Christie ve Geis, 1970; Fehr ve diğ., 1992; Gunnthorsdottir ve diğ., 2002; Kessler ve diğ., 2010).

\subsubsection{Subklinik Psikopati}

Narsisizmde olduğu gibi psikopati psikiyatri ve klinik psikoloji alanında bir kişilik bozukluğunu tanımlarken, subklinik psikopati sosyal ve örgütsel psikoloji alanında kişilik özelliği olarak ele alınmaktadır. Pek çok noktada benzeşen tanımların farkı subklinik psikopatide psikopati eğiliminin daha düşük olmasıdır. Ayrıca psikopati klinik bir tanı iken subklinik psikopatinin tespiti kişinin kendi kendini değerlendirmesi yoluyla yapılmaktadır. Klinik bir hastalığın önceki safhasını ifade eden subklinik psikopatide fark edilebilir klinik belirtiler bulunmamaktadır (Paulhus ve Williams, 2002; Campbell ve diğ., 2010).

Psikopat birey tanımlanırken sıkça fevri (dürtüsel) davranışlar sergiledikleri, diğerlerini küçümseme ve alay etme eğiliminde oldukları, sabırsız, sıkılgan ve uyumsuz oldukları belirtilmektedir (Skeem ve diğ., 2011). Ahlak dışı davranma eğiliminde olan birey, yaptığı davranışlarla ilgili olarak vicdan azabı duymaz. Uzun süreli ilişkileri sürdüremeyen, başkalarına bağlılık ve sadakat gösteremeyen birey için dürtüselliğin uzantısında detaylıca düşünmeden ani ve keskin kararlar almak sıradandır. Dahası, psikopatlar gayri ahlaki davranışlarının sonuçlarından endişe duymazlar ve korkmazlar. Ayrıca ihtiyaçlarının derhal tatmin edilmesini isterler (Spain ve diğ., 2013).

Narsisizm, Makyavelizm ve psikopati yapılarının ortak özellikleri; çok iyi gizlenmekle birlikte sosyal kötü niyet, bencillik, insan ilişkilerinin yüzeysel ve menfaat odaklı olması, uyumsuzluk, ikiyüzlülük, manipülasyona başvurma, duygusal soğukluk ve amaç odaklılık olarak sıralanabilir (Paulhus ve Williams, 2002). Karanlık üçlü kişilik özelliğine sahip bireyler, kişileri ve toplumu etkilemek adına bir takım manipülasyon teknikleri kullanmaktadırlar. Bir başkasına herhangi bir işi, görevi yaptırmak adına o bireye yalan söyleme, tehdit etme, zor kullanma ile o bireyi övme, ona büyüleyici ve etkileyici şekilde davranma tekniklerinin karanlık üçlü kişilik özellikleri için ortak noktalar olduğu söylenebilir (Bayramoğlu, 2019).

Bu gibi davranışsal eğilimlere sahip çalışanın saldırgan davranışlar sergilemesi, astları ya da yöneticileri ile çatışma eğilimine girmesi beklenebilir. Çünkü menfaatlerini ön planda tutması, diğerlerinden üstün olduğu düşüncesi ve diğer pek çok olumsuz 
özelliği diğerlerinin davranışsal özellikleriyle çatışabilir. Bunların yanında güç ve başarı odaklı olan narsist kişilik özelliğine sahip bireylerin iş ve sosyal yaşamlarında stratejik önem taşıyan bir konuma erişme arzusu için çaba göstermeleri beklenebilir (Kanten ve diğ., 2015: 367). Fakat burada önemli olan bu amaç uğruna başvurulan yolların etik olup olmayacağıdır. Madan (2014: 1730), narsistik bireylerin örgütlerde etik olmayan davranışlara daha fazla yöneldiğini belirtmektedir.

\section{Yöntem}

\subsection{Araştırmanın Hipotezleri}

Konaklama işletmesi çalışanlarının demografik özelliklerinin karanlık üçlü üzerinde farklıı̆ğa sebep olup olmadığını belirlemek amacıyla ortaya koyulan hipotezler aşağıda ifade edilmiştir.

$H_{1}$ : Konaklama işletmesi çalışanlarının subklinik narsisizm özellikleri demografik değişkenlere göre farklıık göstermektedir.

$\mathrm{H}_{1 \mathrm{a}}$ : Konaklama işletmesi çalışanlarının subklinik narsisizm özellikleri cinsiyet değişkenine göre farklılık göstermektedir.

$\mathrm{H}_{1 \mathrm{~b}}$ : Konaklama işletmesi çalışanlarının subklinik narsisizm özellikleri medeni durum değişkenine göre farklılık göstermektedir.

$\mathrm{H}_{1 c}$ : Konaklama işletmesi çalışanlarının subklinik narsisizm özellikleri eğitim durumu değişkenine göre farklılık göstermektedir.

$\mathrm{H}_{1 \mathrm{~d}}$ : Konaklama işletmesi çalışanlarının subklinik narsisizm özellikleri çalışma süresi değişkenine göre farklılık göstermektedir.

$\mathrm{H}_{1 \mathrm{e}}$ : Konaklama işletmesi çalışanlarının subklinik narsisizm özellikleri yaş değişkenine göre farklılık göstermektedir.

$H_{2}:$ Konaklama işletmesi çalışanlarının Makyavelizm özellikleri demografik değişkenlere göre farklılık göstermektedir.

$\mathrm{H}_{2 a}$ : Konaklama işletmesi çalışanlarının Makyavelizm özellikleri cinsiyet değişkenine göre farklılık göstermektedir.

$\mathrm{H}_{2 b}$ :Konaklama işletmesi çalışanlarının Makyavelizm özellikleri medeni durum değişkenine göre farklılık göstermektedir.

$\mathrm{H}_{2 c}$ : Konaklama işletmesi çalışanlarının Makyavelizm özellikleri eğitim durumu değişkenine göre farklılık göstermektedir.

$\mathrm{H}_{2 \mathrm{~d}}$ : Konaklama işletmesi çalışanlarının Makyavelizm özellikleri çalışma süresi değişkenine göre farklılık göstermektedir.

$\mathrm{H}_{2 e}$ : Konaklama işletmesi çalışanlarının Makyavelizm özellikleri yaş değişkenine göre farklılık göstermektedir.

$H_{3}$ : Konaklama işletmesi çalışanlarının subklinik psikopati özellikleri demografik değişkenlere göre farklıık göstermektedir. 
$\mathrm{H}_{3 a}$ : Konaklama işletmesi çalışanlarının subklinik psikopati özellikleri cinsiyet değişkenine göre farklılık göstermektedir.

$\mathrm{H}_{3 \mathrm{~b}}$ : Konaklama işletmesi çalışanlarının subklinik psikopati özellikleri medeni durum değişkenine göre farklılık göstermektedir.

$\mathrm{H}_{3 c}$ : Konaklama işletmesi çalışanlarının subklinik psikopati özellikleri eğitim durumu değişkenine göre farklılık göstermektedir.

$\mathrm{H}_{3 \mathrm{~d}}$ : Konaklama işletmesi çalışanlarının subklinik psikopati özellikleri çalışma süresi değişkenine göre farklılık göstermektedir.

$\mathrm{H}_{3 e}$ : Konaklama işletmesi çalışanlarının subklinik psikopati özellikleri yaş değişkenine göre farklılık göstermektedir.

\subsection{Evren ve Örneklem}

Araştırmaya başlamadan önce Akdeniz Üniversitesi Sosyal ve Beşeri Bilimler Bilimsel Araştırma ve Yayın Etiği Kurulu'na başvuruda bulunulmuştur. Yayın Etiği Kurulu'nun planlanan araştırma sürecinin etik olarak uygun olduğuna dair kararı sonrasında araştırmaya katılmayı kabul eden 25 otelin çeşitli departmanlarında çalışan personele araştırmacı tarafından ulaşılmış ve çalışmanın amacı doğrultusunda araştırmaya katılmak isteyenlere anket formu dağıtılmıştır.

Araştırma evrenini Alanya'da faaliyet gösteren dört ve beş yıldızlı otel işletmelerinin çalışanları oluşturmaktadır. Çalışmada evrenin tam sayısına ulaşmak mümkün olmamış ve kazara örnekleme yöntemi kullanılmıştır. 698 personele anket uygulanmış ve 14 anket formu çeşitli nedenlerle değerlendirme dışında tutularak 684 anket formu analizlere dâhil edilmiştir. Veriler, 15 Ağustos-30 Eylül 2019 tarihleri arasında toplanmıştır.

\subsection{Verilerin Toplanması ve Analizi}

Araştırma verileri için birinci bölümünde katılımcıların bireysel özelliklerini belirlemeye yönelik soruların bulunduğu anket formu kullanılmıştır. İkinci bölümde ise Karanlık Üçlü Ölçeği yer almaktadır. Jonason ve Webster (2010) tarafından geliştirilen "Dark Triad Dirty Dozen"ın Türkçe'ye uyarlaması hem Eraslan-Çapan ve diğ. (2015) hem de Özsoy ve diğ. (2017c) tarafından yapılmıştır. Bu çalışmada Eraslan-Çapan ve diğ. (2015) tarafından yapılan uyarlama kullanılmıştır. Ölçekte subklinik narsisizm, Makyavelizm ve subklinik psikopati yapılarının her biri 5'li Likert tipinde dörder madde ile ölçülmektedir. Verilerin analizinde SPSS 22.0 (Statistical Package for Social Sciences) paket programından faydalanılmıştır. Ankette yer alan sorular için frekans dağılımları ve yüzdeleri ile standart sapma ve aritmetik ortalama değerleri hesaplanarak sonuçlar tablolar halinde gösterilmiştir. Katılımcıların bireysel özelliklerinin karanlık üçlü kişilik özellikleri üzerinde belirleyici etkisinin olup olmadığını tespit edebilmek amacıyla bağımsız örneklem t-testi ve Anova testi uygulanmıştır. Karanlık Üçlü ölçeğinin ve alt boyutlarının güvenilirliği Cronbach Alpha $(\alpha)$ katsayısı ile açıklanmıştır.

\section{Bulgular}

\section{1. Ölçeğin Güvenilirliği}


Ölçeğin güvenilirliği, iç tutarlılığı gösteren Cronbach Alpha ( $\alpha$ ) değerleri ile incelenmiştir. Ölçeğin güvenilirlik katsayısı .88'dir ve her bir faktör grubunun güvenilirliğinin .80 değerinin üstünde olması, ölçeğin ve her bir faktör grubunun yüksek derecede güvenilir sınırlar içinde yer aldığı sonucunu ortaya koymaktadır (Kozak, 2017). Ölçek boyutlarına ait Cronbach alpha iç tutarlılık katsayıları aşağıda belirtilmiştir.

Tablo 1: Ölçek ve Alt Boyutlarının Cronbach Alpha (a) Katsayıları

\begin{tabular}{|r|c|c|}
\hline & Madde Sayısı & $\alpha$ \\
\hline Karanlık Üçlü (Toplam) & 12 & 0,88 \\
\hline Subklinik narsisizm & 4 & 0,88 \\
\hline Makyavelizm & 4 & 0,81 \\
\hline Subklinik psikopati & 4 & 0,89 \\
\hline
\end{tabular}

\subsection{Araştırmaya Katılanların Demografik Özelliklerine İlişkin Bulgular}

Örneklem grubunu oluşturan katılımcıların demografik özelliklerine ilişkin bilgiler Tablo 2'de verilmiştir.

Tablo 2: Araştırmaya Katılanların Demografik Özellikleri

\begin{tabular}{|c|c|c|c|}
\hline & f & \multirow{2}{*}{$\begin{array}{c}\% \\
47,51 \\
\end{array}$} \\
\hline Cinsiyet & Erkek & 325 & \\
\hline & Kadın & 359 & 52,49 \\
\hline & Toplam & 684 & 100,00 \\
\hline \multirow{5}{*}{ Eğitim } & İlköğretim & 154 & 22,51 \\
\hline & Ön lisans & 203 & 29,68 \\
\hline & Lisans & 184 & 26,90 \\
\hline & Lisansüstü & 143 & 20,91 \\
\hline & Toplam & 684 & 100,00 \\
\hline \multirow[t]{5}{*}{ Yaş Grubu } & $18-30$ & 239 & 34,94 \\
\hline & $31-45$ & 247 & 36,11 \\
\hline & $46+$ & 198 & 28,95 \\
\hline & Toplam & 684 & 100,00 \\
\hline & Evli & 328 & 47,95 \\
\hline \multirow[t]{2}{*}{ Medeni Durum } & Bekar & 356 & 52,05 \\
\hline & Toplam & 684 & 100,00 \\
\hline \multirow{6}{*}{ İşletmede çalışma süresi } & 1 yıldan az & 162 & 23,68 \\
\hline & $1-5 \mathrm{yll}$ & 128 & 18,71 \\
\hline & $6-10 \mathrm{yll}$ & 128 & 18,71 \\
\hline & $11-15 \mathrm{yll}$ & 143 & 20,91 \\
\hline & $16-20 \mathrm{yll}$ & 123 & 17,98 \\
\hline & Toplam & 684 & 100,00 \\
\hline
\end{tabular}


Araştırmaya katılan çalışanların çoğunluğunun kadın (\%52), 31-45 yaş grubundan (\%36) ve bekâr (\%52) olduğu görülmektedir. \%29,7'si ön lisans mezunu olan örneklemin çoğunluğu bir yıldan az çalışma süresine sahiptir.

\subsection{Katılımcıların Karanlık Üçlü Alt Boyutlarına İlişkin Bulguları}

Tablo 3: Araştırmaya Katılanların Karanlık Kişilik Özellikleri Alt Boyutlarına İlişkin Ortalama, Standart Sapma ve Min.-Max. Değerleri

\begin{tabular}{lcccc}
\hline Değişkenler & Min. & Max. & $\bar{x}$ & S.s. \\
\hline Subklinik Narsisizm & 1.0 & 4.26 & 2.94 & 0.68 \\
\hline Makyavelizm & 1.0 & 4.07 & 2.72 & 0.72 \\
\hline Subklinik Psikopati & 1.0 & 4.96 & 2.68 & 0.69 \\
\hline
\end{tabular}

Ortalama değerler, araştırmaya katılanların her bir boyuta ilişkin kişilik özelliklerinin bir göstergesi olarak ele alınabilir. Ölçeğin tasarımına ve soru kalıplarına göre ortalama değerlerin düşük ya da yüksek olmasının yorumu değişecektir. Bu ölçekte yüksek düzeyde hesaplanan ortalama değerler olumsuz olarak nitelendirilen özelliklerin varlığını ifade etmektedir. Standart sapma değerleri ise gözlem değerlerinin ortalama değerlerden ne derece farklılık gösterdiği konusunda bir fikir vermektedir. Subklinik narsisizm boyutu en yüksek, subklinik psikopati boyutu da en düşük ortalama değere sahiptir.

\subsection{Katılımcıların Demografik Özellikleri ile Karanlık Üçlü Arasındaki Farklılığa İlişkin Bulgular}

Bu bölümde araştırma hipotezlerini test etmek amacıyla yapılan analiz sonuçlarına yer verilmiştir.

Tablo 4: Araştırmaya Katılanların Subklinik Narsisizm Düzeyleri ile Demografik Özellikleri Arasındaki Farklılığa İlişkin t-Testi/Anova Testi/Tukey HSD Sonuçları

\begin{tabular}{|c|c|c|c|c|c|c|c|}
\hline \multicolumn{3}{|c|}{ Demografik Özellikler } & \multicolumn{5}{|c|}{ Subklinik Narsisizm } \\
\hline & & $\mathrm{n}$ & $\overline{\mathrm{x}}$ & ss & $t / F$ & $p$ & $\begin{array}{c}\text { Tukey } \\
\text { HSD }\end{array}$ \\
\hline \multirow{3}{*}{ Cinsiyet } & Erkek & 325 & 3,12 & 0,87 & \multirow{3}{*}{2,725} & \multirow{3}{*}{$0,010^{*}$} & \\
\hline & Kadın & 359 & 2,16 & 1,02 & & & \\
\hline & Toplam & 684 & 2,94 & 0,68 & & & \\
\hline \multirow{5}{*}{ Eğitim } & İlköğretim & 154 & 3,24 & 0,89 & \multirow{5}{*}{2,815} & \multirow{5}{*}{0,102} & \\
\hline & Ön lisans & 203 & 2,54 & 1,14 & & & \\
\hline & Lisans & 184 & 2,82 & 1,22 & & & \\
\hline & Lisansüstü & 143 & 2,62 & 1,28 & & & \\
\hline & Toplam & 684 & 2,94 & 0,68 & & & \\
\hline \multirow{4}{*}{ Yaş Grubu } & $18-30^{x}$ & 249 & 3,24 & 1,02 & \multirow{4}{*}{3,124} & \multirow{4}{*}{$0,036^{*}$} & \multirow{4}{*}{$x, y$ ve $z$} \\
\hline & $31-45^{y}$ & 237 & 2,54 & 1,19 & & & \\
\hline & $46+^{2}$ & 198 & 1,82 & 0,90 & & & \\
\hline & Toplam & 684 & 2,94 & 0,68 & & & \\
\hline \multirow{3}{*}{ Medeni Durum } & Evli & 328 & 2,15 & 1,01 & \multirow{3}{*}{1,523} & \multirow{3}{*}{$0,003^{*}$} & \\
\hline & Bekar & 356 & 2,95 & 1,09 & & & \\
\hline & Toplam & 684 & 2,94 & 0,68 & & & \\
\hline
\end{tabular}


Tablo 4'ün devamı

\begin{tabular}{|c|c|c|c|c|c|c|}
\hline İşletmede & 1 yıldan az & 162 & 2,44 & 0,79 & 0 & 0950 \\
\hline & $1-5$ yıl & 128 & 2,19 & 1,02 & & \\
\hline & 6-10 yıl & 128 & 2,16 & 1,02 & & \\
\hline & 11-15 yıl & 143 & 2,15 & 1,18 & & \\
\hline & $16-20$ yıl & 123 & 1,81 & 1,22 & & \\
\hline & Toplam & 684 & 2,94 & 0,68 & & \\
\hline
\end{tabular}

${ }^{*} p<0.05$

Tablo 4'te katılımcıların Subklinik Narsisizm düzeyi farklılıklarını belirlemeye yönelik cinsiyet ve medeni durum değişkenleri için yapılan t-testi sonuçları ile eğitim düzeyi, çalışma süresi ve yaş değişkenleri için yapılan Anova testi sonuçları yer almaktadır. Elde edilen bulgulara göre çalışanların subklinik narsisizm seviyeleri cinsiyet $(t=2,725, p=0,010<0,05)$, medeni durum $(t=1,523, p=0,003<0,05)$ ve yaş $(F=3,124$, $p=0,036<0,05)$ faktörlerine göre anlamlı bir farklılık göstermektedir $(p<0,05)$. Bekâr çalışanların subklinik narsisizm düzeyleri evli çalışanlara göre daha yüksektir. Erkek çalışanların subklinik narsisizm düzeyleri ise kadın çalışanlara göre daha yüksektir. Ayrıca çalışanların yaş grupları ile subklinik narsisizm seviyeleri arasında negatif yönlü ve anlamlı ilişki tespit edilmiştir. Farklı grupları belirlemeye yönelik yapılan Tukey testi sonucuna göre, 18-30 yaş grubuna dâhil olan katılımcıların subklinik narsisizm seviyeleri diğer yaş gruplarına göre daha fazladır $(p<0,05)$. Elde edilen sonuçlara göre turizm sektöründe çalışanların yaşları arttıkça subklinik narsisizm seviyeleri azalmaktadır.

Subklinik narsisizm seviyeleri işletmede çalışma süresi ve eğitim değişkenlerine göre anlamlı farklılık göstermemiştir $(p<0,05)$. Bu durumda araştırmanın $\mathrm{H}_{1 \mathrm{a}}, \mathrm{H}_{1 \mathrm{~b}}$ ve $\mathrm{H}_{1 \mathrm{e}}$ hipotezleri kabul edilirken $\mathrm{H}_{1 \mathrm{c}}$ ve $\mathrm{H}_{1 \mathrm{~d}}$ hipotezleri kabul edilmemiştir.

Tablo 5: Araştırmaya Katılanların Makyavelizm Düzeyleri ile Demografik Özellikleri Arasındaki Farklılığa İlişkin t-Testi ve Anova Testi Sonuçları

\begin{tabular}{|c|c|c|c|c|c|c|}
\hline \multicolumn{3}{|c|}{ Demografik Özellikler } & \multicolumn{4}{|c|}{ Makyavelizm } \\
\hline & & $\mathrm{n}$ & $\bar{x}$ & Ss & $t / F$ & $p$ \\
\hline \multirow[t]{3}{*}{ Cinsiyet } & Erkek & 325 & 2,84 & 0,77 & \multirow{3}{*}{2,965} & \multirow{3}{*}{$0,006^{*}$} \\
\hline & Kadın & 359 & 2,29 & 1,12 & & \\
\hline & Toplam & 684 & 2,72 & 0,72 & & \\
\hline \multirow[t]{5}{*}{ Eğitim } & İlköğretim & 154 & 3,17 & 0,79 & \multirow{5}{*}{1,824} & \multirow{5}{*}{0,102} \\
\hline & Ön lisans & 203 & 2,64 & 1,24 & & \\
\hline & Lisans & 184 & 2,42 & 1,32 & & \\
\hline & Lisansüstü & 143 & 2,22 & 1,38 & & \\
\hline & Toplam & 684 & 2,72 & 0,72 & & \\
\hline \multirow[t]{4}{*}{ Yaş Grubu } & $18-30$ & 249 & 3,54 & 1,12 & \multirow{4}{*}{3,124} & \multirow{4}{*}{0,116} \\
\hline & $31-45$ & 237 & 2,84 & 1,39 & & \\
\hline & $46+$ & 198 & 2,81 & 1,90 & & \\
\hline & Toplam & 684 & 2,72 & 0,72 & & \\
\hline
\end{tabular}


Tablo 5'in devamı

\begin{tabular}{|c|c|c|c|c|c|c|}
\hline \multirow[t]{3}{*}{ Medeni Durum } & Evli & 328 & 2,34 & 1,21 & \multirow{3}{*}{1,753} & \multirow{3}{*}{$0,023^{*}$} \\
\hline & Bekar & 356 & 2,97 & 1,19 & & \\
\hline & Toplam & 684 & 2,72 & 0,72 & & \\
\hline \multirow{6}{*}{$\begin{array}{l}\text { İşletmede çalışma } \\
\text { süresi }\end{array}$} & 1 yıldan az & 162 & 2,68 & 0,89 & \multirow{6}{*}{2,255} & \multirow{6}{*}{0,312} \\
\hline & $1-5 \mathrm{yll}$ & 128 & 2,29 & 1,22 & & \\
\hline & $6-10$ yıl & 128 & 2,19 & 1,32 & & \\
\hline & $11-15$ yıl & 143 & 2,56 & 1,68 & & \\
\hline & $16-20$ yıl & 123 & 2,81 & 1,42 & & \\
\hline & Toplam & 684 & 2,72 & 0,72 & & \\
\hline
\end{tabular}

${ }^{*} p<0.05$

Tablo 5'te katılımcıların Makyavelizm düzeyi farklılıklarını belirlemeye yönelik cinsiyet ve medeni durum değişkenleri için yapılan t-testi sonuçları ile eğitim düzeyi, çalışma süresi ve yaş değiş̧enleri için yapılan Anova testi sonuçları yer almaktadır. Elde edilen bulgulara göre çalışanların Makyavelizm seviyeleri cinsiyet $(t=2,965$, $p=0,006<0,05)$ ve medeni durum $(t=1,753, p=0,023<0,05)$ faktörlerine göre anlamlı bir farklılık göstermektedir $(p<0,05)$. Subklinik Narsisizmde olduğu gibi bekâr ve erkek çalışanların Makyavelizm düzeyleri evli ve kadın çalışanlara göre daha yüksektir. Fakat subklinik narsisizmde etkili olan yaş faktörü Makyavelizm boyutunda farklılığa sebep olmamıştır.

Makyavelizm seviyeleri işletmede yaş, çalışma süresi ve eğitim değişkenlerine göre anlamlı farklılık göstermemiştir $(p<0,05)$. Bu durumda araştırmanın $\mathrm{H}_{2 a}$ ve $\mathrm{H}_{2 b}$ hipotezleri kabul edilirken $\mathrm{H}_{2 c}, \mathrm{H}_{2 \mathrm{~d}}$ ve $\mathrm{H}_{2 \mathrm{e}}$ hipotezleri kabul edilmemiştir.

Tablo 6: Araştırmaya Katılanların Subklinik Psikopati Düzeyleri ile Demografik Özellikleri Arasındaki Farklılığa İlişkin t-Testi ve Anova Testi Sonuçları

\begin{tabular}{|c|c|c|c|c|c|c|}
\hline \multicolumn{3}{|c|}{ Demografik Özellikler } & \multicolumn{4}{|c|}{ Sabklinik Psikopati } \\
\hline & & $n$ & $\overline{\mathrm{x}}$ & SS & $t / F$ & $p$ \\
\hline \multirow{3}{*}{ Cinsiyet } & Erkek & 325 & 2,64 & 0,83 & \multirow{3}{*}{2,675} & \multirow{3}{*}{$0,013^{*}$} \\
\hline & Kadın & 359 & 2,49 & 1,12 & & \\
\hline & Toplam & 684 & 2,68 & 0,69 & & \\
\hline \multirow{5}{*}{ Eğitim } & İlköğretim & 154 & 2,87 & 0,99 & \multirow{5}{*}{1,756} & \multirow{5}{*}{0,872} \\
\hline & Ön lisans & 203 & 2,54 & 1,94 & & \\
\hline & Lisans & 184 & 2,92 & 1,32 & & \\
\hline & Lisansüstü & 143 & 2,47 & 1,38 & & \\
\hline & Toplam & 684 & 2,68 & 0,69 & & \\
\hline \multirow{4}{*}{ Yaş Grubu } & $18-30$ & 249 & 2,94 & 1,02 & \multirow{4}{*}{2,128} & \multirow{4}{*}{0,096} \\
\hline & $31-45$ & 237 & 2,74 & 1,09 & & \\
\hline & $46+$ & 198 & 2,51 & 1,87 & & \\
\hline & Toplam & 684 & 2,68 & 0,69 & & \\
\hline
\end{tabular}


Tablo 6'nın devamı

\begin{tabular}{|c|c|c|c|c|c|c|}
\hline \multirow[t]{3}{*}{ Medeni Durum } & Evli & 328 & 2,47 & 1,08 & \multirow{3}{*}{1,753} & \multirow{3}{*}{0,210} \\
\hline & Bekar & 356 & 2,27 & 1,19 & & \\
\hline & Toplam & 684 & 2,68 & 0,69 & & \\
\hline \multirow{6}{*}{$\begin{array}{l}\text { İşletmede çalışma } \\
\text { süresi }\end{array}$} & 1 yıldan az & 162 & 2,12 & 0,87 & \multirow{6}{*}{1,295} & \multirow{6}{*}{0,252} \\
\hline & $1-5 \mathrm{yll}$ & 128 & 2,39 & 1,32 & & \\
\hline & 6-10 yıl & 128 & 2,29 & 1,65 & & \\
\hline & $11-15$ yıl & 143 & 2,26 & 1,78 & & \\
\hline & $16-20 \mathrm{yıl}$ & 123 & 2,31 & 1,93 & & \\
\hline & Toplam & 684 & 2,68 & 0,69 & & \\
\hline
\end{tabular}

${ }^{*} p<0.05$

Tablo 6'da katıımcıların subklinik psikopati düzeyi farklılıklarını belirlemeye yönelik cinsiyet ve medeni durum değişkenleri için yapılan t-testi sonuçları ile eğitim düzeyi, çalışma süresi ve yaş değişkenleri için yapılan Anova testi sonuçları yer almaktadır. Elde edilen bulgulara göre çalışanların subklinik psikopati seviyeleri subklinik narsisizm ve Makyavelizm'de olduğu gibi cinsiyet $(t=2,675, p=0,013<0,05)$ faktörüne göre anlamlı bir farklılık göstermektedir $(p<0,05)$.

Makyavelizm seviyeleri işletmede medeni durum, yaş, çalışma süresi ve eğitim değişkenlerine göre anlamlı farklılık göstermemiştir $(p<0,05)$. Bu durumda araştırmanın $\mathrm{H}_{3 a}$ hipotezi kabul edilirken $\mathrm{H}_{3 b}, \mathrm{H}_{3 c}, \mathrm{H}_{3 d}$ ve $\mathrm{H}_{3 e}$ hipotezleri kabul edilmemiştir.

\section{Tartışma ve Sonuç}

Bu çalışmanın amacı turizm sektörü çalışanlarının karanlık kişilik seviyelerini belirlemek ve bu özelliklerin demografik özelliklere göre farklılık gösterip göstermediğini ortaya koymaktır. Bu amaçla Alanya'da faaliyet gösteren otel işletmelerinde bir alan araştırması yapılmıştır.

Araştırma bulgularına göre otel işletmesi çalışanlarının subklinik narsisizm kişilik özelliğine dair ortalamaları diğer alt boyutlara göre daha fazladır. Subklinik narsisizmi sırasıyla Makyavelizm ve subklinik psikopati takip etmektedir.

Bağımsız değişkenlerin alt boyutlar üzerindeki etkisine ayrı ayrı bakıldığında ise cinsiyetin tüm alt boyutlarda etkili olduğu görülmektedir. Erkek çalışanların karanlık kişilik özellikleri kadın çalışanlara göre daha fazladır. Bu sonuç Özcihan (2014) ve Hamedoğlu'nun (2009) çalışma sonuçlarıyla benzerlik göstermektedir. Özcihan (2014) ve Hamedoğlu'nun (2009) araştırma sonuçlarına göre de erkek çalışanların narsisizm düzeyleri kadın çalışanlara göre daha yüksektir. Diğer yandan Akıncı (2015) ve Özer ve diğ.'nin (2016) çalışma bulgularına göre cinsiyet, karanlık kişilik boyutları üzerinde farklılığa sebep olmamıştır.

Ayrıca medeni durum ve yaş, karanlık kişiliğin subklinik narsisizm boyutunu açıklamada etkilidir. Bekâr çalışanların subklinik narsisizm düzeyleri evli çalışanlara göre daha yüksektir. Çalışanların yaş grupları ile subklinik narsisizm seviyeleri arasında negatif yönlü ve anlamlı bir ilişki tespit edilmiştir. 18-30 yaş grubuna dâhil olan katılımcıların subklinik narsisizm seviyeleri diğer yaş gruplarına göre daha fazladır. Elde edilen sonuçlara göre turizm sektöründe çalışanların yaşları arttıkça subklinik narsisizm seviyesi azalmaktadır. Araştırma sonucunda subklinik narsisizm ile ilgili elde edilen 
veriler daha önceki çalışma sonuçlarıyla benzer niteliktedir. Nitekim Akıncı da (2015) araştırmasında yaşın narsisizmde etkili olduğunu ve yetişkinliğin erken dönemlerinde narsisizmin daha ileri yaşlara göre daha yüksek olduğunu tespit etmiştir. Yine Aydoğan ve Serbest (2016) bu sonucu mesleğin başlarında olan ve genç olarak adlandırılabilecek olan katılımcıların beklentilerinin ve hedeflerinin yüksek olması şeklinde yorumlamıştır. Özer ve diğ.'nin (2016) araştırma sonuçlarına göre de medeni durum ve yaş subklinik narsisizm üzerinde belirleyicidir. Hamedoğlu (2009), erkeklerin kadınlara göre daha yüksek düzeyde narsisistik özellikler göstermesini çocukluk yıllarından başlayarak erkeklerdeki narsistik eğilimlerin aileler tarafından daha fazla beslenmesine bağlamaktadır. Eğitim durumu ve çalışma süresi subklinik narsisizm düzeyleri üzerinde anlamlı bir farklılığa sebep olmamıştır.

Bu sonuçlara göre, kendisinde bulunan nitelikleri abartmak, kendini eşsiz ve ayrıcalıklı hissetmek, güç sahibi olmayı önemsemek, empati yapamamak, diğerlerine karşı kuşkucu ve güvensiz olmak, kişisel intiyaç ve menfaatleri her zaman ön planda tutmak ve eleştirilere tahammül edememek gibi subklinik narsisizm özelliklerinin zamanla azaldığını söylemek mümkün görünmektedir. Nitekim genç katılımcıların ileri yaştaki katılımcılara göre subklinik narsisizm düzeyleri daha fazladır. Bireyler ilerleyen yaşla birlikte çalışma yaşamında daha uyumlu ve kanaatkâr olabilirler. Kişilerin kurumda ilgi odağı olma, deneyimleriyle ilgili intikam alma, istediklerini elde etmede hileli yollara başvurma, elindeki bilgiyi başka birine karşı kullanma gibi eğilimlerinde azalmalar görülebilir. Ayrıca ilerleyen yaşla birlikte insan ilişkilerinde olgunlaşmadan ve barışçıl ilişkiler kurma arayışından söz edilebilir. Evliliğin de birlikte yaşamayı gerektirdiği için bireysel düşünmeyi azalttığı, evlendikten sonra duygusal paylaşımların ve sorumlulukların artması ile narsistik eğilimlerin azaldığı düşünülebilir. Erkek çalışanların subklinik narsisizm düzeylerindeki fazlalık ise geleneksel aile yaşamındaki yetiştirilme tarzından kaynaklanıyor olabilir.

Her ne kadar narsisizmin tehlikeli boyutlara ulaşmadığı sürece gerekli ve değerli bir eğilim olduğunu (Cihangiroğlu, 2012: 122), ruh sağlığına fayda sağladığını, duygusal anlamda olumlu sonuçlar yaratabileceğini (Campbell ve Foster, 2007: 114) ifade eden araştırmacılar olsa da narsist kişilere ait özelliklerin örgüt yaşamında istenmeyen özellikler olduğunu söylemek mümkündür. Bu anlamda kişiler arası ilişkilerin ve ekip çalışmasının son derece önemli olduğu turizm sektöründe hizmet kalitesinin, müşteri memnuniyetinin ve sadakatinin müşteriyle birebir iletişim halinde olan turizm işletmesi çalışanlarına bağlı olduğu düşünüldüğünde bencil, egosu yüksek ve kendini diğerlerinden üstün ve değerli gören çalışanların örgüte zarar vereceğini söylemek yanlış olmayacaktır.

Araştırmanın diğer sonuçları çalışanların Makyavelizm seviyelerinin cinsiyet ve medeni durum faktörlerine, subklinik psikopati seviyelerinin ise sadece cinsiyet faktörüne göre anlamlı bir farklılık göstermesidir. Subklinik narsisizmde olduğu gibi bekâr ve erkek çalışanların Makyavelizm düzeyleri evli ve kadın çalışanlara göre daha yüksektir. Benzer şekilde Ergun Özler ve diğ. (2013), erkek çalışanların makyavelist eğilimlerinin kadın çalışanlardan yüksek olduğunu tespit etmiştir. Subklinik psikopati düzeyleri de erkek çalışanlarda daha yüksektir. Jones ve Figueredo (2012) da yaptıkları araştırmada karanlık üçlü kişilik özelliğinin erkeklerde kadınlardan daha yüksek düzeyde olduğunu; özellikle psikopati kişilik özelliğinin erkeklerde daha yüksek düzeyde olduğunu belirlemişlerdir. Eğitim durumu, çalışma süresi ve yaş makyavelizim üzerinde etkili değildir. Benzer şekilde, eğitim durumunun istatistiksel olarak anlamlı bir değişken olmadığını belirten çalışmalar (Hamedoğlu, 2009; Atay, 2009) olduğu gibi eğitim durumu, yaş ve cinsiyetin çalışanların makyavelist eğilimlerinde etkisinin olduğunu belirten çalışmalar da (Ergun Özler ve diğ., 2013; Özcihan, 2014; Özer ve diğ., 2016) 
bulunmaktadır. Eğitim durumu bu çalışmada hiçbir alt boyut üzerinde etkili olmamıştır. Bu durumda araştırmanın $\mathrm{H}_{2 a}$ ve $\mathrm{H}_{2 b}$ hipotezleri kabul edilirken $\mathrm{H}_{2 c}, \mathrm{H}_{2 d}$ ve $\mathrm{H}_{2 e}$ hipotezleri kabul edilmemiştir.

Karanlık kişilik ölçeğinin bütün boyutlarında cinsiyet faktörünün farklılığa sebep olması Türkiye'deki kültürel yapıya ve geleneksel aile yapısına bağlanabilir. Kadını çocuk bakımı ve ev işlerinden sorumlu tutan geleneksel yapıda, kadınlar için sadece evle ilgili (domestik) rolün, erkekler için de gelir getiren birey rolünün uygun olduğu görüşü ile büyütülmenin, erkek çalışanların iş yaşamında kadın çalışanlara nazaran daha rekabetçi olmalarına sebep olduğu söylenebilir.

Turizm işletmelerinin birbirine benzer hizmet ve ürün sunduğu piyasa şartlarında farklılığı ve müşteri memnuniyetini sağlayacak olan, hizmeti birebir müşteriye sunan insan kaynağıdır. Bu açıdan standart hizmetleri fark yaratacak şekilde sunacak olan beşeri sermayenin sahip olduğu kişisel özellikler konaklama işletmeleri açısından önemlidir. Her ne kadar işe alımlar belirli eleme ölçütlerine göre yapılsa da ilk aşamada bu özelliklerin belirlenememesi intimali de vardır. Bu açıdan turizm işletmesi yöneticilerine çalışan davranışlarını gözlemlemeleri, karanlık üçlü eğilimlerine dair ölçüm yapmaları ve bu eğilimleri azaltmaya yönelik eğitim programları düzenlemeleri önerilebilir.

Araştırmada nicel araştırma yöntemi kullanılmıştır. Nicel araştırma, araştırmacıya genelleştirilebilir sonuçlar üretmesi ve farklı gruplar arasında karşılaştırmaya fırsat vermesi açısından yardımcı olurken mükemmel nitelik ve sayıda örneklem almanın güçlüğü ve ölçme aracının önyargıyı da yansıtma intimali gibi sınırlılıkları mevcuttur. Ayrıca karanlık üçlü (subklinik narsisizm, makyavelizm ve subklinik psikopati) nesnel olarak değerlendirilmesi güç olan kavramlardır ve kişiyi kendi beyanına dayalı ölçüm araçları ile değerlendiriyor olmanın sınırlılığını taşımaktadır. Yapılan araştırmanın bulguları ve kullanılan ölçeklerin güvenilirliği örneklem grubunda yer alan kişilerin verdikleri yanıtlar ile sınırlıdır. Araştırmanın örneklemi Alanya'da faaliyet gösteren 4 ve 5 yıldızlı 25 otel ve 684 çalışandan oluşmaktadır. Dolayısıyla bulguların tüm otel işletmesi çalışanlarına genellenemeyeceği göz ardı edilememelidir. Konuyu farklı sektördeki örneklem gruplarıyla ele almak bir başka araştırmanın konusu olabilir. Böylelikle sektörler arasında karşılaştırma yapma fırsatı ortaya çıkabilecektir.

\section{Kaynakça}

Akıncı, İ. (2015), The Relationship Between the Types of Narcissism and Psychological Well-Being: The Roles of Emotions and Difficulties in Emotion Regulation, Yayınlanmamış Yüksek Lisans Tezi, ODTÜ, Sosyal Bilimler Enstitüsü, Ankara.

Amernic, J. H. ve Craig,R. J. (2010), "Accounting as a Facilitator of Extreme Narcissism", Journal of Business Ethics, 96 (1), ss. 79-93.

Ames, R., Rose, P. ve Anderson, C. P. (2006),"The NPI-16 as a short measure of narcissism", Journal of Research in Personality, 40, ss. 440-450.

Atay, S. (2009), "Narsistik Kişilik Envanteri'nin Türkçe'ye Standardizasyonu", Gazi University Journal of Economics \& Administrative Sciences, 11(1), ss.181-196.

Aydoğan, E. ve Serbest, S. (2016),"İş Yerinde Karanlık Üçlü: Bir Kamu Kuruluşunun İç Denetim Biriminde Araştırma", Sayıştay Dergisi, 101, ss. 97-121.

Bayramoğlu, E. (2019),Ölümlülük Manipülasyonunun, Bağlanma Türlerinin ve Karanlık Üçlü Kişilik Özelliklerinin Risk Alma Davranışına Etkisi. Yayımlanmamış Yüksek Lisans Tezi, Maltepe Üniversitesi, Sosyal Bilimler Enstitüsü, İstanbul. 
Brunell, A. B., Gentry, W. A., Campbell, W. K.,Hoffman, B. J.,Kuhnert, K. W. ve DeMarree, K. G. (2008), "Leader Emergence: The Case of the Narcissistic Leader, Personality and Social Psychology Bulletin,34(12), ss. 1663-1676.

Campbell, W. K. ve Foster, J. D. (2007), "The Narcissistic Self: Background, An Extended Agency Model, and Ongoing Controversies, (ed.) C. Sedikides and S. Spencer, Frontiers in Social Psychology: The Self,, ss. 115-138, ABD: Phileadelphia.

Campbell, W.K., Hoffman, B. J., Campbell, S. M. ve Marchisio, G. (2010), "Narcissism in organizational contexts", Human resource management review, 21, ss. 268284.

Campbell., W. K. ve Miller, J. D. (2011), The Handbook of Narcissism and Narcissistic Personality Disorder: Theoretical Approaches, Empirical Findings, and Treatments, New York: John Wiley \& Sons.

Christie, R. ve Geis,F. L. (1970), Studies in Machiavellianism, New York: Academic Press.

Cihangiroğlu, N. (2012), "Narsistik Kişilik ile Kurumsal Bağlılık Arasında Bir İlişki Var mıdır?", TAF Preventive Medicine Bulletin,11(2), ss.119-126.

Eraslan-Çapan, B., Satıcı,S. A., Yılmaz,M. F. ve Kayış,A. R. (2015), "Karanlık Üçlü Ölçeği: Türkçeye uyarlama çalışması", 13. Ulusal Psikolojik Danışma ve Rehberlik Kongresi, 7-10 Ekim, Mersin, Türkiye.

Ergun Özler, D., Atalay Gider, C. ve Dirican, M.(2013), "Örgütlerin Karanlık Yüzü Makyavelizm İle İlgili Literatür Taraması ve Çalışanların Makyavelist Eğilimlerini Belirlemeye Yönelik Bir Araştırma", 21. Ulusal Yönetim Ve Organizasyon Kongresi Bildiriler Kitabı, Kütahya, ss. 679-685.

Fehr, B., Samsom, D. ve Paulhus, D. L. (1992), The construct of Machiavellianism: Twenty years later. İçinde, C. D. Spielberger ve J. N. Butcher (Eds.), Advances in personality assessment, 9, ss 77-116, Hillsdale, NJ: Erlbaum.

Furnham, A., Richards, S.C., ve Paulhus, D.L. (2013),"The Dark Triad of personality: A 10 year review", Social and Personality Psychology Compass, 7, ss. 199-216.

Galperin, B. L., Bennett,R. J. ve Aquino,K. (2011), "Status Differentiation and the Protean Self: A Social-Cognitive Model of Unethical Behavior inOrganizations", Journal of Business Ethics, 98 (3), ss. 407-424.

Gunnthorsdottir, A., McCabe, K. ve Smith, V. (2002), "Using the Machiavellianism instrument to predict trustworthiness in a bargaining game", Journal of Economic Psychology, 23, ss. 49-66.

Hamedoğlu, M. A. (2009), Örgütsel Narsizim Düzeyine İlişkin Yönetici ve Öğretmen Algıları, Yayımlanmamış Doktora Tezi, Hacettepe Üniversitesi, Sosyal Bilimler Enstitüsü, Ankara.

Harms, P. D. ve Spain, S. M. (2015),"Beyond the Bright Side: Dark Personality at Work", Applied Psychology: An International Review, 64(1), ss.15-24.

Harms, P. D., Spain,S. M. ve Wood,D. (2014), "Mapping Personality in Dark Places", Industrial and Organizational Psychology, 7 (1), ss. 114-117.

Jonason, P.K. ve Webster, G.D. (2010), "The Dirty Dozen: A concise measure of the Dark Triad", Psychological Assessment, 22, ss. 420-432.

Jonason, P. K., Wee,S. ve Li,N. P. (2015), "Competition, Autonomy, and Prestige:Mechanisms through which the Dark Triad Predict Job Satisfaction", Personality and Individual Differences, 72, ss. 112-116.

Jones, D. N. ve Figueredo, A. J. (2012), "The core of darkness: Uncovering the heart of the dark triad", European Journal of Personality, 27(6), ss. 521-531.

Jones, D. N. ve Paulhus, D.L. (2011), "The role of impulsivity in the dark triad of personality", Personality and Individual Differences, 51, ss. 679-682.

Jones, D. N. ve Paulhus,D. L. (2014), "Introducing the Short Dark Triad (SD3): A Brief Measure of Dark Personality Traits", Assessment, 21 (1), ss. 28-41. 
Kanten, P., Yeşiltaş, M. ve Arslan, R. (2015), "Kişiliğin karanlık yönünün üretkenlik karşıtı iş davranışlarına etkisinde psikolojik sözleşmenin düzenleyici rolü", Atatürk Üniversitesi İktisadi ve Idari Bilimler Dergisi, 29, ss. 931-259.

Kessler, S. R., Bandelli, A. C., Spector, P. E.,Borman, W. C., Nelson,C. E. ve Penney,L. M.(2010), "Re-examining Machiavelli: A Three-Dimensional Model of Machiavellianism in the Workplace", Journal of Applied Social Psychology,40 (8), ss. $1868-1896$.

Kiazad, K., Restubog, S. L. D., Zagenczyk, T. J., Kiewitz, C. ve Tang,R. L. (2010), "InPursuit of Power: The Role of Authoritarian Leadership in the Relationship between Supervisors' Machiavellianism and Subordinates' Perceptions of Abusive Supervisory Behavior", Journal of Research in Personality, 44 (4), ss. 512-519.

Kozak, M. (2017), Bilimsel Araştırma: Tasarım, Yazım ve Yayım Teknikleri. 3. Basım, Detay Yayıncılık, Ankara.

Madan, A. O. (2014), "Cyber Aggression / Cyber Bullying and the Dark Triad: Effect on Workplace Behavior/ Performance", International Journal of Social, Management, Economics and Business Engineering, 8(6), ss.1725-1730.

Maples, J. L., Lamkin, J. ve Miller, J. D. (2014), "A test of two brief measures of the Dark Triad: The dirty dozen and short Dark Triad", Psychological Assessment, 26, 326331.

McDonald, M.M., Donnellan, M.B. ve Navarrete, C.D. (2012). A life history approach to understanding the Dark Triad. Personality and Individual Differences, 52, ss. $601-$ 605.

Nagler, U. K. J., Reiter, K. J.,Furtner, M. R. ve Rauthmann,J. F. (2014), "Is There a“Dark Intelligence"? Emotional Intelligence is Used by Dark Personalities to Emotionally Manipulate Others", Personality and Individual Differences, 65,ss. 47-52.

O'Boyle, E. H. Jr, Forsyth, D. R., Banks, G. C. ve McDaniel, M. A. (2012),"A metaanalysis of the Dark Triad and work behavior: A social exchange perspective", Journal of Applied Psychology, 97, ss. 557-579.

Özcihan, T. (2014), Organizasyonlarda Stratejik Duygusal Zekâ Kullanımı Makyavelizm İlişkisi ve Çatışma Yönetimine Yansıması: Tasarım Mühendisliğinde Bir Araştırma, Yayımlanmamış Yüksek Lisans Tezi, Anadolu Üniversitesi, Sosyal Bilimler Enstitüsü, Eskişehir.

Özen Kutanis, R., Özsoy, E., Karakiraz, A. ve Uslu, O. (2015), "Örgütsel Davranış Araştırmalarında Kişiliğin Karanlık Yönü (Narsisizm, Makyavelizm ve Psikopati) Dikkate Alınıyor mu?", 23. Ulusal Yönetim ve Organizasyon Kongresi, 14-16 Mayıs, Muğla Sıtkı Koçman, Muğla.

Özer, Ö., Uğurluoğlu, Ö. Kahraman, G. ve Avcı, K. (2016), "Hemşirelerin Karanlık Kişilik Özelliklerinin Sosyo-Demografik Değişkenler Açısından İncelenmesi", CBÜ Sosyal Bilimler Dergisi, 14(3), ss. 203-2016.

Özsoy, E. ve Ardıç, K. (2017), "Karanlık Üçlü'nün (Narsisizm, Makyavelizm ve Psikopati) İş Tatminine Etkisinin İncelenmesi", Yönetim ve Ekonomi, 24(2), ss. 391-406.

Özsoy, E., Ardıç, K. ve Balaban, Ö. (2017a), "Karanlık Üçlü’nün Örgütsel Bağııı̆ga Etkisinin İncelenmesi", Politik, Ekonomik ve Sosyal Araştırmalar Kongresi Bildiri Özetleri Kitabı,9-11 November, 2017, Ankara.

Özsoy, E., Ardıç, K. ve Balaban, Ö. (2017b),"Karanlık Üçlü'nün Yöneticiye Güvene Etkisinin İncelenmesi", Politik, Ekonomik ve Sosyal Araştırmalar Kongresi Bildiri Özetleri Kitabı, 9-11 November, 2017, Ankara

Özsoy, E., Rauthmann, J. F., Jonason, P. K., ve Ardıç, K. (2017c), "Reliability and validity of Turkish version of Dark Triad Dirty Dozen (DTDD-T), Short Dark Triad (SD3-T) and Single Item Narcissism Scale (SINS-T)", Personality and Individual Differences, 117, ss. 11-14 
Paulhus, D. L. ve Williams, K. M. (2002), "The Dark Triad of personality: Narcissism, Machiavellianism and psychopathy", Journal of Research in Personality, 36, ss. 556-563.

Penney, L. M. ve Spector,P. E. (2002), "Narcissism and Counterproductive Work Behavior: Do Bigger Egos Mean Bigger Problems?", International Journal of Selection and Assessment, 10 (1/2), ss. 126-134.

Raskin, R. ve Terry, H. (1988), "A principal-components analysis of the narcissistic personality inventory and further evidence of its construct validity", Journal of Personality and Social Psychology, 545, ss. 890-902.

Robinson, S. L. ve O'Leary-Kelly,A. M. (1998), "Monkey See, Monkey Do: The Influence of Work Groups on the Antisocial Behavior of Employees", Academy of Management Journal, 41 (6), ss. 658-672.

Rosenthal, S. A. ve Pittinsky,T. L. (2006), "Narcissistic Leadership", The Leadership Quarterly, 17, ss. 617-633.

Schyns, B. (2015), "Dark personality in the workplace: Introduction to the special issue",Applied Psychology: An International Review, 64, ss. 1-14.

Sığrı, Ü. ve Gürbüz, S. (2011),"Akademik Başarı ve Kişilik İlişkisi: Üniversite Öğrencileri Üzerinde Bir Araştırma", Savunma Bilimleri Dergisi, 10 (1), ss. 30-48.

Skeem, J. L., Polaschek, D. L. L., Patrick, C. J. ve Lilienfeld, S. O. (2011), "Psychopathic personality: bridging the gap between scientific evidence and public policy", Psychological Science in the Public Interest, 12, ss. 95-162.

Spain, S. M., Harms, P. ve LeBreton,J. M. (2013), "The Dark Side of Personality at Work", Journal of Organizational Behavior, 35 (1), ss. 41-60.

T.C.

AKDENIZ UNTVERSITESI

Sosyal ve Beşeri Bilimler Bilimsel Araştırma ve Yayın Etiği Kurulu RARAR

$\begin{array}{ll}\text { Toplantı Tarih } & : 20 / 11 / 2019 \\ \text { Karar Sayıs } & : 211\end{array}$

Üniversitemiz Rektörlüğgü Öğr. Gör. Dr. Esin YƯCEL'in yürütŭcülüğünü üstlendiği, "Kişiligin Karanlkk Üçlüsū: Turizm Sektörūnde Demografik Değiş̧kenler Açıııdan Bir Araştırma" başlıklı bilimsel araştırma projesi kapsamında kullanilacak olan anket çalıșmasının uygunluğunun gōrüşülmesi istemi.

Ûniversitemiz Rektörlüğü Öğr. Gör. Dr. Esin YỨcEL'in yürütücuีlüğ̄inü

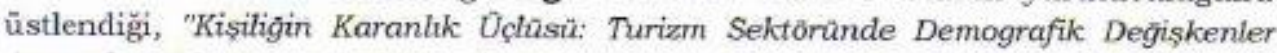
Açısından Bir Araştırma" konulu anket çalışmasmın, fikri hukuki ve telif hakları bakımından metot ve ölçeğine iliş̧kin sorumluluğun başvurucuya ait olmak đ̃zere, proje süresince uygulanmasının etik olarak uygun olduğuna oy birliği ile karar verilmiștir. 